\title{
Conceptual foundations of sustainable development of territorial-spatial entities
}

\author{
Yury Gusev ${ }^{1, *}$, and Tatiana Polovova ${ }^{2}$ \\ ${ }^{1}$ All-Russian Research Institute "Tsentr", Moscow, Russia \\ ${ }^{2}$ Moscow Municipal University of Management of the Moscow City Government named after Yu. M. \\ Luzhkov, Moscow, Russia
}

\begin{abstract}
The need to form mechanisms for ensuring the sustainable functioning and development of regional economic systems causes a change in the forms of organization and integration of production on an innovative basis. This is becoming a priority task in conducting scientific research in the field of organizing the activity of territorial-spatial entities (TSE), assessing and monitoring the sustainability of their development in a strategic terms. At the same time, this can be realized only by determining the vector of sustainability in the presence of risk factors of the external environment and development trends of both TSE and the region's economy as a whole. In this regard, in the article, in the context of the innovative development of regional economic systems, the conceptual foundations of ensuring the sustainability of territorial-spatial entities are considered as forms of the integration of industries, focused on the creation of innovation of the value of products (services).
\end{abstract}

\section{Introduction}

In modern conditions, an important feature in the activities of territorial-spatial entities and the economy of the regions as a whole is the validity and adequacy of managerial impacts on the parameters of resource potential, using appropriate methods, as well as reasonable management decisions at the appropriate level in the context of ensuring sustainable economic development, growth of added value and the standard of living of the population [1].

With the successes, achieved in improving the institutional and infrastructural innovation environment in the domestic economy at the regional level, there is still an extremely weak introduction and commercialization of novations in the absence of systematic support for innovative activity from the federal authorities. In this regard, fixed assets at the end of 2019 had a physical depreciation of $46.8 \%$, fully depreciated fixed assets accounted for $18.7 \%$, depreciation of machinery and equipment was $27.8 \%$ [2]. In addition, there is obsolescence for a significant list of fixed assets. This aspect and the negative dynamics of the state of fixed assets in view of the low rates of their renewal and disposal of worn-out and out-dated equipment leads to production inefficiency, as well as

\footnotetext{
*Corresponding author: gusev.yury@icloud.com
} 
often to the inability to produce products with the properties of "value innovation" for potential consumers.

Thus, ineffective innovation policy leads to low rates of innovation implementation, which significantly affects the sustainability of the regional economy.

In this regard, it is necessary to pay special attention to the study and implementation in the national innovation economy of the experience of ensuring the innovative activity of enterprises and territorial-spatial entities, the commercialization of innovations.

The research conducted on the level of innovative development and the sustainability of the functioning of regional economies allow to draw a number of conclusions. At the same time, the main conclusion is the extremely weak study of methodological and conceptual provisions of the influence on positive changes in the development of the economy of innovations and innovations of the value of products and services. It is the innovation of the value of products and services that is the key result of innovation activity of economic entities, integrated within TSE.

This primarily applies to regions with a depressed economy $[3 ; 4 ; 5$, etc.].

Thus, the strategic management of sustainable trends in the development of the regional economy should be based on effective management of economic entities, integrated into united territorial-spatial entities. This will provide conditions for the formation of an optimal portfolio of innovative TSE projects, innovative susceptibility and performance of activity.

\section{Research methods}

The research of the above problems is based on the toolkit of dialectical methods of cognition, which provide a methodological basis for their comprehensive and objective study. At the same time, scientific knowledge on the problem under study is substantiated by means of analysis, synthesis, generalizations, induction, deduction.

To solve the problems posed above, institutional provisions, the current legislation of the Russian Federation in terms of state and regional management, territorial development, as well as scientific works of scientists-economists on regional economics and the sustainability of economic systems were used.

In order to form the information base, the published materials on the studied territorialspatial entities, as well as the official statistical materials of Rosstat, were studied.

In this regard, in order to substantiate the author's position on the indicated problems on the basis of general scientific methods of abstraction and generalization, a theoretical analysis of various points of view and scientific views, set forth in the publications of scientists-economists, was carried out, as well as a synthesis of the materials obtained. In addition, the experience of the authors of this article as experts is used.

Practical research was carried out using methods such as: observation; study of open sources.

The evidence base for substantiating the hypothesis is based on the method of comparative analysis, which allowed to compare different approaches to transforming the innovative structure of the national economy and building an infrastructure, adequate to the technological challenges of the 4 th industrial revolution.

This makes it possible to substantiate approaches to ensuring the sustainability of the development of territorial-spatial entities with a particular focus on the potential of the regional economy and trends in innovative development, as well as the risks, caused by various factors of the internal and external environment, including those, associated with the transition of the economy to a new technological paradigm.

Thus, the strategic vector of innovative development within the framework of the concepts of integration of participants in market relations will ensure the sustainability of 
economic systems, territorial-spatial entities, taking into account the resource potential of the regional economy $[6 ; 7$, etc. $]$.

\section{Results of research}

In the modern national economy, one of the central places is occupied by the process of transforming the infrastructure of the regional economy through the development of potential capabilities and economic growth of territorial-spatial entities (such as clusters, megalopolises, technology parks, innovation and technology centers, technology transfer centers, etc.) in the context of innovative priorities of the 6th technological paradigm [8;9; $10 ; 11 ; 12$, etc.].

Note, that the scale of challenges in the field of innovative development of economic entities is constantly increasing. This is due, firstly, to the shift in priorities of innovative development towards technological trends of the 6th technological paradigm, and secondly, to the weak susceptibility of domestic economic entities to novations.

It is the systemic and purposeful transformation of the regional economy, that becomes an important tool for achieving its sustainable development.

At the same time, some positive trends in the transformation of infrastructure and the formation of an innovative business environment in the economy should be noted.

More than 150 technology parks, innovation and technology centers and technology transfer centers operate in the regions of Russia [2]:

Central Federal District - 55;

Northwestern Federal District - 24;

Southern Federal District - 16;

Volga Federal District - 24;

Ural Federal District - 6;

Siberian Federal District - 21;

Far Eastern Federal District - 7.

This gives an idea of the trends in the innovation focus of new innovative structures with modern intellectual resources, capable of creating highly-demanded innovations of the value of products (services).

Thus, conditions are created to ensure the development of the economy, based on an integrated economic environment in the TSE format. By implementing innovative projects, that correspond to modern technological trends, such economic systems become an innovative platform in the structure of the regional economy.

The created innovative potential becomes the basis for interregional cooperation and through breakthrough technologies provides access to the markets for high-tech products with signs of innovation of value $[13 ; 14 ; 15 ; 16 ; 17$, etc.].

In modern conditions, within TSE, it is possible to solve three main tasks, regarding such key aspects as development, innovation, strategic management, and sustainability.

1. To become an entrepreneurial environment for innovative projects, the implementation of which is carried out within the framework of national projects and venture capital investments. Thus, there is a basis for the formation of an innovative strategy in conditions of fierce competition in the technology and innovation market.

2. To ensure the specialization of the economy, based on the selection of priorities, focused on the technological directions of the 6th technological paradigm, in accordance with the available intellectual potential.

3. To ensure the transformation of its own innovation infrastructure with the financial support of development projects by the federal government.

Thus, territorial-spatial entities, as a result of sectoral (intersectoral) integration, being a key tool for the development of the regional economy on an innovative basis, are able to 
provide investment attractiveness and sustainability of the economy in the strategic terms $[15 ; 17 ; 18 ; 19$, etc. $]$.

In this regard, a sustainability management concept is needed, that reflects at least the integration of the two approaches.

Management of sustainable development of the TSE economy through a set of methods and means of strategic management of the activities of economic systems, capable of adapting to the risks and uncertainties of environmental factors.

Formation of value orientations for consumers of products (services), that ensure advantages in the market, including as a result of integration on an innovative basis of the interests of economic entities, located in different regions.

This conclusion is confirmed in publications on this issue, for example $[4 ; 20 ; 21 ; 22$, etc.].

The author's vision of the formation of economic sustainability management is based on the interrelation of the following theoretical and methodological provisions.

Firstly, the concept of strategic management, which provides opportunities through the influence on the performance of business entities to achieve the target function of the activity of the business entity $[23 ; 24 ; 25$, etc. $]$.

Secondly, the theory of risks, the implementation of the concepts of which makes it possible to limit the impact on the results of activity of crisis processes, which are a consequence of the manifestation of negative factors of the external and internal environment, as well as managerial impacts [26; 27, etc.].

Thirdly, the ability to generate and implement (including through integration with other economic systems) innovations with exclusive consumer values. In this case, we are talking about the concept of consumer values, which in the context of this research takes the form of "value innovation".

Thus, the concept of managing the economic sustainability of territorial-spatial entities is based on the integration of the concept of strategic management, value concept and risk theory.

Through this integration, we get a tool for the multivariate formation of scenarios of strategies for the development of the regional economy, depending on the state of the resource potential and changes in the path of sustainability of economic entities. Preferred trends of the level of economic sustainability of economic systems, environmental risk factors and other circumstances are the result of long-term measures to ensure sustainable advantages in the strategic terms.

The state and dynamics of sustainability of TSE within the framework of the concept of strategic management is determined on the basis of the sustainability assessment methodology. The conducted research in this context allowed to formulate several conceptual provisions regarding the content of parameters for assessing sustainability.

As the first parameter of the assessment, based on the system of indicators, the resource potential is taken as the intra-system environment of territorial-spatial entities or the region as a whole. The presence of this parameter is due to the interdependence of the factors of the state of the structure of the resource potential, in which changes in some factors become the cause of quantitative and qualitative changes in others, which leads to a violation of the sustainability of the economic system. In this case, the resource potential is considered from the standpoint of the ability to create innovation of the value of a product (service). This conclusion is confirmed in publications on this issue, for example [7;22, etc.]

Factors of strategic risks of the external environment, as a result of the interaction of the economic system with the external environment in the exchange of products (services), is the second parameter in assessing sustainability.

The presence of the third parameter is due to the impact of synergy factors on the level of sustainability. The assessment is based on the idea, that the elements of synergy have a 
stronger influence on the state of all parameters of the potential in the presence of a correct and sufficient amount of control action on the sensitive points of bifurcation of the infrastructure of the regional economy as a system [28].

The degree of unintended consequences, arising from changes in the state of the parameters of the resource potential of the economic system under the impact of negative factors or untapped opportunities is the fourth parameter for assessing sustainability. The main provisions of this aspect are set forth in the works of a number of researchers $[29 ; 30$, etc.].

Fig. 1 shows a model of strategic management of sustainable development of territorialspatial entities

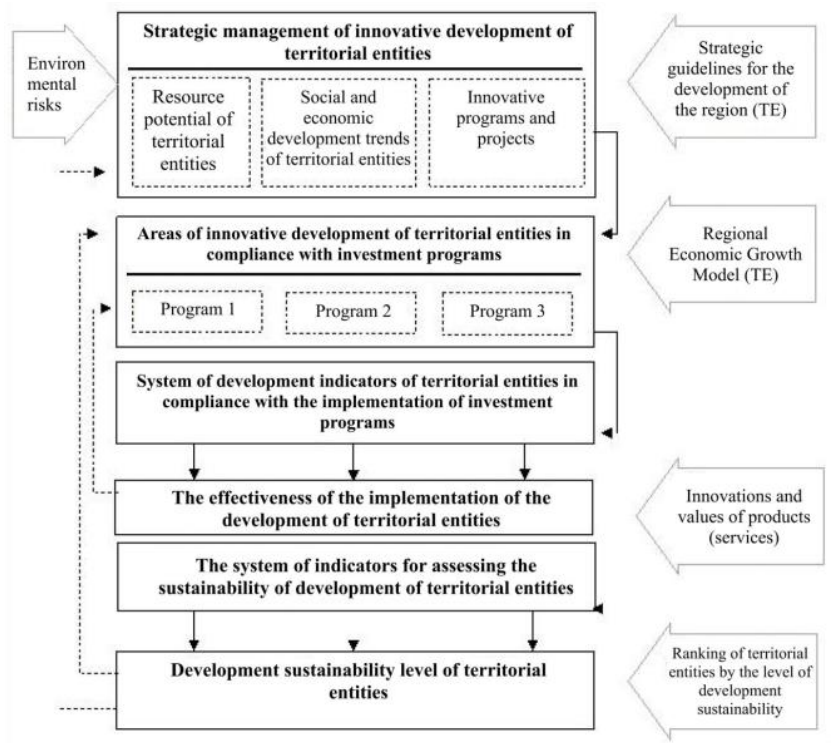

Fig. 1. A model of strategic management of sustainable development of territorial-spatial entities

In the proposed model of strategic management, the system for assessing the sustainability of the regional economy (TSE) is the tool that ensures the effective implementation of the scenarios of the economic development pathway. Such an assessment system allows monitoring the achievement of strategic goals through the created innovation of the values of products and services.

\section{Results and discussion}

Studying issues in the field of innovation theory, innovation management, as well as the innovative development of organizations is carried out by both domestic and foreign specialists.

The points of view and positions of scientists-economists on the issues under study are presented in Table 1.

Studying issues on the outlined topics allowed us to conclude, that in the economic literature, scientists explain viewpoint sufficiently detailed from the position of:

- socio-economic policy in the regions [B.M. Grinchel, B.S. Zhikharevich, S.V. Kuznetsov, N.M. Mezhevich, V.E. Rokhchin, V.M. Khodachek and others];

- the main provisions of the concepts of innovative development of the economy and territorial entities [S.Yu. Glazyev, V.V. Ivanov, B.N. Kuzyk, D.S. Lvov, Yu.V. Yakovets, B. Lundwall, R. Nelson, M. Porter, K. Freeman and others]; 
- assessment of the level of innovative and investment development of territories [L.Yu. Adadimova, E.P. Amosenok, V.A. Bazhanov, T.N. Danilova, L.I. Egorova, A.M. Ilyshev, Yu.G. Polulyakh, V.V. Spitsyn and others];

- innovative and investment development, determined by strategic trends and priorities in the economy [S.N. Valdaitsev, P. Drucker, K. Clark, N.D. Kondratyev, M.Yu. Mitrofanov, R.M. Nizhegorodtsev, V.M. Razumovsky, B. Santo, etc.];

- development of the theory of risks, taking into account the factors of uncertainty and sustainability of the economy [I.T. Balabanov, Yu.L. Vorobiev, Yu.Yu. Ekaterinoslavsky, U. King, A.A. Lobanov, F.Kh. Knight, E.M. Rogova, K. Redhead, E.F. Utkin, A.N. Fomichev, S. Hughes and others].

The conclusions and proposals of scientists, based on the results of research in the field of sustainable development of the regional economy, are relevant not only from the point of view of science, but are of practical importance and are widely implemented in innovation activity at the macro-meso and micro levels.

In the presence of a significant number of research in the field of managing sustainable development of the regional economy in a strategic terms, it is necessary to conclude, that not all problematic issues were resolved. On a number of issues, scientists-economists did not arrive at a consensus. In particular, we are talking about methodological approaches and methodological provisions, regarding the content of the concept of assessment, monitoring and management of the sustainability of the regional economy.

This is relevant in the context of the joint creation and exchange of values in the process of interaction between market participants, obtaining a synergistic effect as a result of the integration and use of the experience of each other.

Of course, it is necessary to conduct a lot of research on these issues before rather solid methodological approaches and appropriate techniques are formed, that objectively reflect the trends in the sustainability of the regional economy.

For this purpose, an attempt was made to substantiate the basic conceptual provisions of managing the innovative (sustainable) development of territorial-spatial entities and assessing their sustainability.

\section{Conclusion}

The results of the research allowed to identify the positions of scientists-economists regarding the features of the current state of the regional economy, including in terms of innovation processes in territorial-spatial entities, the essence, patterns and assessment of the sustainability of economic systems, etc.

It is noted, that the current stage of economic development has a number of features, in particular:

- at the regional level, there is still an extremely weak introduction and commercialization of innovations due to limited investments;

- as a result of the existing innovation policy, there is a low rate of innovation implementation, which significantly affects the sustainability of the regional economy;

- the processes of integration of business entities have been fast-tracked in order to generate and create value for products (services), which are based on innovation. 
Table 1. Positions of scientists-economists on the issues under study.

\begin{tabular}{|c|c|}
\hline Problems under study & Domestic and foreign scientists \\
\hline $\begin{array}{l}\text { Development of innovative } \\
\text { activity and the activity of } \\
\text { economic entities in the system of } \\
\text { clusters, megalopolises and other } \\
\text { territorial-spatial entities }\end{array}$ & $\begin{array}{l}\text { Aleshin A.V., Alieva E.M., Asaul A.N., Gusev Yu.V., } \\
\text { Ivanter V.V., Isaeva E.M., Mensh G., Nikulina O.V., Nelson } \\
\text { R., Perani J., Polovova T.A., Rodionova N.D., Skoch A.V., } \\
\text { Trofimova O.M., Chernikov E.A., Chernova O.A., } \\
\text { Shevchenko I.K. Schumpeter J.A. and others. }\end{array}$ \\
\hline $\begin{array}{l}\text { Research of innovative processes } \\
\text { in territorial-spatial entities }\end{array}$ & $\begin{array}{l}\text { Asaul A.N., Bakhtizin A.R., Bogdan N.I., Bodrunov S.D., } \\
\text { Bortnik I.M., Glazyev S.Yu., Glisin F.F., Golichenk O.G., } \\
\text { Gokhberg L M., Ivanova N.I., Ivanter V.V., Kuznetsov S.V., } \\
\text { Lundvall B., Malinin A. M., Mensh G., Nelson R., Perani J., } \\
\text { Razumovsky V.M., Santo B., Twiss B., Freeman K., } \\
\text { Schumpeter J.A., Edqvist Ch., et al. }\end{array}$ \\
\hline $\begin{array}{c}\text { Modern aspects of regional } \\
\text { development }\end{array}$ & $\begin{array}{l}\text { O.G. Golichenko, B.M., L.M. Gohber, Grinchell, B.S. } \\
\text { Zhikharevich, N.M. Mezhevich, A.I. Tatarkin, J.-F. Tiss, } \\
\text { A.M. Khodachek, R.N. Shniper, S.N. Yashin and others. }\end{array}$ \\
\hline $\begin{array}{l}\text { Strategic management and } \\
\text { innovation management }\end{array}$ & $\begin{array}{l}\text { K.V. Baldin, A.V. Barysheva, S.Yu. Glazyev, A.P. Gradov, } \\
\text { A.G. Granberg, V.F. Ershov, V.S. Kabakov, N.N. } \\
\text { Kolosovsky, G.A. Krayukhin, V.L. Makarov, I.V. Pilipenko, } \\
\text { V.P. Semyonov, I.I. Sidorov, V.N. Starinskiy and others. }\end{array}$ \\
\hline $\begin{array}{l}\text { Issues of assessing the } \\
\text { sustainability of economic } \\
\text { systems }\end{array}$ & $\begin{array}{l}\text { Foreign scientists: I. Ansoff, S.L. Bru, A. Wald, L. Walras, } \\
\text { R. Cantillon, J. Keynes, O. Cournot, K.R. McConnell, A. } \\
\text { Marshall, L. Mises, J.S. Meal, F. Knight, W. Pareto, G.A. } \\
\text { Simon, P. Samuelson, A. Smith, J. Schumpeter and others. } \\
\text { Domestic scientists: A.N. Asaul, S.P. Baranenko, I.V. } \\
\text { Bryantsev, O.G. Bodrov, A.N. Golovina, Yu.V. Gusev, E.A. } \\
\text { Kozlova, A.A. Kolobov, R.M. Magomedov, L.S. Portnyagin, } \\
\text { B.A. Raizberg, E.S. Stoyanova, S.V. Chupronov and others. }\end{array}$ \\
\hline $\begin{array}{l}\text { Problems of studying the essence } \\
\text { and patterns of sustainability of } \\
\text { economic systems }\end{array}$ & $\begin{array}{l}\text { A.A. Andronov, A.N. Asaul, V.P. Astakhov, E.A. Barbyshev, } \\
\text { L. von Bertalanffy, V.V. Bolotin, A.S. Volmir, S.L. Bru, A. } \\
\text { Wald, L. Walras, J. Lagrange, A.M. Lyapunov, I.G. Malkin, } \\
\text { L.S. Portnyagin, I. Prigozhin, S. Poisson, A.R. Rzhanitsin, } \\
\text { S.P. Timoshenko and others. }\end{array}$ \\
\hline
\end{tabular}

Source: compiled by the authors

In this regard, it was concluded, that the methodological and conceptual provisions of the influence on positive changes in the development of the economy of innovation as an important component of the value of products and services were insufficiently discussed.

Within the framework of the research, it was established, that in order to increase the innovative susceptibility and performance of business entities, it is necessary to substantiate approaches to ensuring the sustainability of economic development. One of these approaches is the strategic management of economic entities, integrated into single territorial-spatial entities. This allowed to systematically and in unity to focus on the potential of the region's economy and trends in innovative development, as well as the risks, caused by various factors of the internal and external environment, including those, associated with the transition of the economy to a new technological paradigm.

The results of the study allow to state, that a number of generalizations and conclusions, made regarding the conceptual foundations of sustainable development of territorial-spatial entities in the context of global economic, innovative and technological changes develop modern management theory.

Further research of the above issues allow to substantiate a number of provisions regarding the transformation of a complex of management tasks to enhance innovative development and ensure the sustainability of the regional economy. 


\section{References}

1. On the Strategy for Spatial Development until 2025: Order dated February 13, 2019 No. 207-r. (as revised on 31.08.2019). Access from the reference legal system "ConsultantPlus"

2. Federal State Statistics Service. https://www.gks.ru/folder/14304.

3. Ekaterina L. Vodolazhskaya, Viktor I. Abramov, Sofia Sh. Ostanina, Alexey D. Chudnovskiy, Maxim A. Suchkov, Larisa F. Zhandarova, Alla A. Rybolovleva, Guzel B. Sayfutdinova, International journal and marketing, Int. Review of Management and Marketing 6 (S2), 212 (2016)

4. S.V. Kuznetsov, Problems of transformation and regulation of regional socioeconomic systems, St. Petersburg, 45 (2019)

5. Rating of innovative development of the constituent entities of the Russian Federation. https://issek.hse.ru/rirr2020

6. I.A. Rudskaia, D.G., Rodionov, L.A. Guzikova, Actual problems of economy 158 (8), 215 (2014)

7. S.V. Kuznetsov, E.A. Gorin, On the efficiency of using regional industrial potential. In the collection: Regional economy and development of territories. Collection of scientific articles. Saint Petersburg, 15 (2019)

8. P. Ya. Baklanov, Izv. RAS. Ser. geogr. 4, 7 (2017)

9. Yu. V. Gusev, T. A. Polovova, Stage: economic theory, analysis, practice 5, 22 (2017)

10. S.S. Demin, E.A. Avduevskaya, Russian Economic Internet J. 3, 28 (2018)

11. O.V. Zaborovskaya, T. N. Selentieva, Russian Economic Internet Journal 4, 41 (2018)

12. S.V. Terebova, Economic and Social Changes: Facts, Trends, Forecast 6, 199 (2014)

13. B.M. Grinchel, E.A. Nazarova, Innovations 8 (226), 105 (2017)

14. A.I. Shinkevich, F.F. Galimulina, V.O. Moiseyev, V.V. Avilova, K.S. Kuramshina, I.I. Ishmuradova, L.A. Ponkratova, V.L. Grankina, International Review of Management and Marketing (IRMM) 6 (2), 142 (2016)

15. M.V. Shinkevich, A.I. Shinkevich, A.D. Chudnovskiy, I.I. Ishmuradova, L.V. Marfma, T.A. Zhuravleva, International 25 J. of Economics and Financial Issues (IJEFI) 6 (l), 179 (2016)

16. K.V. Nazvanova, Economic Analysis: Theory and Practice 16 (2 (461)), 251 (2017).

17. A.A. Rumyantsev, Economic and social changes: facts, trends, forecast 11 (2), 84 (2018)

18. B.M. Grinchel, E.A. Nazarova, Russian Regions: Competitive Attractiveness and Development Sustainability (Publishing House of the St. Petersburg State University of Aerospace Instrumentation, St. Petersburg, 2019)

19. A.A. Zaitsev, Bulletin of the International Academy of Agrarian Education 25(2), 238 (2015)

20. B.M. Grinchel, E.A. Nazarova, Economics and Management 26 (1(171)), 23 (2020)

21. B.S. Zhikharevich, National interests: priorities and security 1, 34 (2018)

22. A.P. Tyapukhin, Yu.I. Korovin, O.B. Matveeva, Bulletin of Eurasian Science 5 (2019). https://esj.today/PDF/47ECVN519.pdf

23. BS Zhikharevich, Regional Economy. South of Russia 1(19), 16 (2018) 
24. E.V. Zhogova, A.A. Zaitsev, D.G. Rodionov, Russian Economic Internet J. 2, 35 (2019)

25. Y. V. Gusev, T.A. Polovova, I. Karnaukh, J. of Applied Economic Sciences XI (43), 968 (2016)

26. Yu. V. Gusev, T. A. Polovova, Enterprise Management in Conditions of Uncertainty and Risks: Problems and Solutions: monograph, 146 p. (Moscow, 2018)

27. B.S. Zhikharevich, Regional Economy. South of Russia 8(4), 19 (2020)

28. Yu. V. Gusev, T. A. Polovova, Economics and Entrepreneurship 3(68-1), 806 (2016)

29. A.M. Khodachek, Innovations 10 (240), 27 (2018)

30. Yu. V. Gusev, T. A. Polovova, Bulletin of SibADI 3(43), 116 (2015) 